Jarosław Filip CZUB

Warszawa

\title{
Reprezentacja polskich grup biznesowych w systemie instytucjonalnym Unii Europejskiej a rzetelne rzecznictwo interesów
}

\footnotetext{
$\mathbf{P}$
} olskie grupy biznesowe stanowią formę ogniwa pośredniczącego pomiędzy organami Unii Europejskiej (UE) a członkami lub organizacjami (konfederacjami narodowymi $^{1}$ ), które reprezentują. Według kodeksu postępowania lobbystów ${ }^{2}$ grupy interesu są pełnoprawnym elementem w systemach demokratycznych, a dzięki swojej silnej pozycji są w stanie czynnie i biernie partycypować w procesie decyzyjnym UE i w poszczególnych krajach członkowskich. Jednakże negatywne konotacje związane z działalnością grup biznesowych w społeczeństwie polskim przyczyniają się do nieprawidłowego postrzegania grup interesu funkcjonujących $w$ granicach ram prawnych. Prawdziwe rzetelne rzecznictwo interesów jest często mylone $\mathrm{z}$ fenomenem korupcjogennych zachowań i załatwiania spraw po tak zwanej ,znajomości”. Takie generalne postrzeganie grup biznesowych przez społeczeństwo budzi wiele kontrowersji. Takie postrzeganie grup biznesowych skłoniło autora artykułu do postawienia następującej tezy badawczej: reprezentacja polskich grup biznesowych a rzetelne rzecznictwo interesów w systemie instytucjonalnym UE.

Unia Europejska w 2007 roku znalazła się w historycznym punkcie swego rozwoju, kiedy to wówczas nastapiło kolejne jej rozszerzenie do 27 krajów członkowskich. Tak wielka liczba państw członkowskich z jednej strony daje szerokie możliwości rozwoju Unii jako całości, z drugiej strony stawia nowe wyzwania integracyjne. Możliwość dynamicznego rozwoju mogą zapewnić między innymi rzetelne polskie przedstawicielstwa, które będąc w bliskim kontakcie z instytucjami europejskimi mają istotny wpływ na proces decyzyjny UE i jednocześnie na pogłębiającą się integrację krajów członkowskich i ich rozwój na poziomie narodowym i ponadnarodowym.

Samo pojęcie rzecznictwa interesów ma swoje daleko idące korzenie płynące zza oceanu. Stany Zjednoczone Ameryki są pierwszym krajem, w którym lobbing zaczynał nabierać coraz to większego rozmachu. Miało to już miejsce w XIX wieku podczas budowy kolei żelaznych. Jej urzeczywistnienie wywoływało kontrowersje wokół których zaczął krystalizować się i sankcjonować lobbing ${ }^{3}$.

Po drugiej wojnie światowej w latach osiemdziesiątych i dziewięćdziesiątych w Brukseli pojawiły się pierwsze grupy nacisku i stopniowo zaczęły ugruntowywać swoją pozycję. W tym także okresie zaczęły powstawać także nowe ośrodki, które działając w innych sekto-

\footnotetext{
${ }^{1}$ Organizacje te skupiają między innymi: pracodawców, firmy, federacje narodowe, inne organizacje, a także członków reprezentujących różnorodne interesy ekonomiczno-przemysłowe.

${ }^{2}$ Lobbyści - przedstawiciele grup biznesowych.

${ }^{3}$ W efekcie końcowym lobbing został usankcjonowany poprzez ustawę w 1946 roku - Federal Regulation of Lobbying Act of 1946; J. L. Zorack, The Lobbying Handbook, Washington 1990, s. 23, 1027.
} 
rach miały i mają ogromny wpływ wspólnotowy na proces decyzyjny. Lobbing na poziomie ponadnarodowym poprzez pogłębianie zakresu przedmiotowego i rozszerzanie zakresu terytorialnego integracji europejskiej stale rozszerza swoje znaczenie.

Terminologia współczesnego lobbingu jest mało klarowana i nadużywana. Nazewnictwo związane z lobbingiem jest przypisywane etykiecie lobbingu organizacjom takim jak: grupy interesu, grupy nacisku, lobbys - organizacje, firmy lobbingowe, czy grupy adwokackie. Każde z tych pojęć niesie za sobą szczególny aspekt aktywności będący przejawem reprezentowania różnorodnych interesów. Grupy interesu są nazywane różnie w zależności od regionu, z którego pochodzą. W anglosaskiej literaturze są wzajemnie zamienialne używane sformułowania grupy lobbingowe, grupy nacisku, lobbing, lobbyst. Powszechnie w światowej literaturze nie ma przyjętego określonego terminu, który charakteryzowałby grupy interesu. Konkludując należy posługiwać się wzajemnie zamienialnymi formami, które odnoszą się do nomenklatury grup interesu.

Generalnie ujmując sama terminologia lobbingu („lobbyist”) wykrystalizowała się w USA w XIX wieku, kiedy to interesanci indywidualnie oczekiwali w parlamentarnym lobby (przedsionku, korytarzu) w celu przeprowadzenia korzystnych rozmów i wywierania wpływu na postawy i decyzje kongresmenów. Po raz pierwszy słowo lobby zostało użyte do opisania przykrytej (dachem) alei, korytarza w klasztorze (,,a covered alley in a monastery”). Spożytkowanie tejże terminologii nastąpiło w 1870 r. w związku z decyzją amerykańskiego Generała Granta, który z przyczyn zewnętrznych (pożar w Białym Domu) musiał przenieść swoją siedzibę do pobliskiego hotelu. Tym samym ,,pomieszkując" i pracując tam przyjmował swoich interesantów w holu wejściowym (entrance hall). Ta część hotelu nosiła nazwę lobby i w konsekwencji po wielu spotkaniach z interesantami zaczęto nazywać ich lobbystami (,lobbyists”) ${ }^{4}$. Tym samym należy podkreślić, że nazewnictwo korytarza (corridor, lobby) nabrało innowacyjnego znaczenia opisując ludzi-interesantów podejmowanych przez osoby ze środowiska polityki.

Lobbing stał się ekskluzywną działalnością komercyjną. Jest pewną formą pozwalającą na prawidłową komunikację pomiędzy zainteresowanymi stronami - pomiędzy tymi, którzy ustanawiają pewne przepisy i akty normatywne a tymi, którzy chcą wywierać wpływ na decyzje dotyczące ich klientów (rządu danego państwa czy grupy państw, firmy komercyjnej, stowarzyszenia, organizacji pozarządowej i innych). Przedstawiciele grup biznesowych nie pełnią jedynie funkcji związanej z aktywną działalnością lobbingową („lobbying activity”), reprezentują nie tylko zainteresowane strony, czy pełnią funkcję obrony interesów zainteresowanych stron korzystną decyzją, lecz także biorą bardzo aktywny udział w życiu politycznym, dostarczają cennych informacji, przedstawiają swoje racje, bądź udzielają porad parlamentarzystom, komisarzom, grupom społecznym związanych z komitetami (np. Komitet Ekonomiczno-Społeczny, Komitet Regionów). Należy podkreślić także, że lobbing zawiera w sobie sztukę prowadzenia negocjacji i prowadzenia takiej dyplomacji, która odniesie kluczowy sukces mający wpływ na dalekosiężne decyzje. Lobbingu nie należy w obecnych czasach przedstawiać jako formę przedstawicielstwa interesów, lecz także jako formę reprezentacji poszczególnych grup społecznych organizacji rządowych czy innych.

W literaturze naukowej funkcjonuje wiele definicji grup interesu. Badaniem terminologii grup interesu zajmują się między innymi następujący badacze: Giuliani, Lefebure, Olson,

\footnotetext{
${ }^{4}$ P. Goergen, Lobbying In Brussels, Brussels 2006, s. 14.
} 
Greenwood, Kurczewska, Sroka, Jasiecki, Molenda-Zdziech, Kotler, Le Grelle, Coxall, Collison, McGrath czy Zorack.

W literaturze naukowej występują następujące definicje grup biznesowych:

- Casidy - grupy interesu stanowią narzędzie wpływu wykorzystywane przez wielkie korporacje do nakłaniania polityków do podejmowania dla lobbystów kluczowych decyzji. Dosłownie przedstawia tą kwestię jako „seduce politicians”, czyli „nęcenia”, „kuszenia” polityków;

- Almond i Powell - uważają, że grupy interesu składają się z poszczególnych jednostek połączonych więzami wspólnych interesów i korzyści, a członkowie tychże grup mają świadomości istnienia tych powiązań;

- Van Schendelen - działalność grup interesu odnosi się do wszelkiego rodzaju nieszablonowych działań podejmowanych przez te organizacje w celu uzyskania pożądanego efektu, który leży w gestii rządu.

Urszula Kurczewska i Małgorzata Molenda-Zdziech, wskazują, że lobbing jest formą rzecznictwa interesów a jego istotą jest w dużym stopniu zamiar wywierania wpływu na procesy decyzyjne w pewnych ośrodkach, instytucjach władzy ${ }^{5}$. Należy jednak zauważyć, że samo pojęcie lobbingu w głównej mierze jest rodzajem narzędzia, które ma na celu wywieranie wpływu.

Poza literaturą naukową występują następujące definicje grup biznesowych:

- ustawa z dnia 7 lipca 2005 roku o działalności lobbingowej w procesie stanowienia prawa - w art. 2 ust. 1 tejże ustawy możemy odczytać, że działalnością lobbingową jest prowadzenie działań metodami prawnie dozwolonymi zmierzajace do wywarcia wplywu na organy władzy publicznej w procesie stanowienia prawa. Art. 2 ust. 2 dodaje, że lobbing jest działalnościq dochodowa, którq prowadzi się na rzecz trzeciej strony działajac wich imieniu;

- Komisja Europejska - za reprezentowanie grup interesu rozumie sie działania majace na celu wywarcie wptywu na procesy ksztaltowania polityki i podejmowania decyzji przez instytucje europejskie. Komunikat Komisji, Europejska Inicjatywa na rzecz przejrzystości, Zasady dotyczące stosunków z przedstawicielami grup interesu (rejestr i kodeks postępowania, Zielona Księga z 3 maja 2006 roku, komunikat z 21 marca 2007).

Podsumowując powyższe analizy terminologiczne, grupy biznesowe można zdefiniować jako:

Organizacje biznesowe sq podmiotami podejmującymi działania lobbingowe majace na celu rzecznictwo interesów określonych grup pochodzacych z różnych sektorów. Stanowia formę aktywności, która ma wplyw na określone ośrodki wladzy poprzez przekonywanie, namawianie, dostarczanie $i$ wymiane informacji oraz wystawianie swoich postulatów i rozwiqzań mających na celu usatysfakcjonowanie zainteresowanych stron (instytucji europejskich, grup interesu, określonych grup spolecznych i innych).

Polskie grupy biznesowe powstawały głównie ze względu na:

— zmiany systemu politycznego w Polsce po 1989 roku (np. Związek Banków Polskich - 1991, Polska Konfederacja Pracodawców Prywatnych Lewiatan - 1999, Krajowa Izba Gospodarcza - 1990);

${ }^{5}$ U. Kurczewska, M. Molenda-Zdziech, Lobbing w Unii Europejskiej, Warszawa 2002, s. 13-19. 
— cel powstania - poszukiwanie wspólnych płaszczyzn wymiany doświadczeń i reprezentacji jednym głosem wspólnych interesów;

— wprowadzenie zmian w 1989 roku w prawie gospodarczym na wielu płaszczyznach;

- rozwój korporacji i pracodawców prywatnych, a także prywatnych inicjatyw jak: banki z większościowym udziałem kapitału z sektora prywatnego;

— stymulacja wywołana chęcią mówienia jednym głosem w poszczególnych sektorach gospodarczych, jak w przypadku Związku Dealerów Samochodów (ZDS);

— akcesję Polski do UE.

\section{Reprezentacje polskich grup biznesowych posiadają następujące cechy:}

— składają się z jednostek, które reprezentują podobne interesy na poszczególnych płaszczyznach;

— reprezentują jednosektorowość lub wielosektorowość z danej branży;

- charakteryzują się długofalowym procesem lub stanowią grupe ad-hoc stworzoną dla jednego projektu;

- reprezentują swoich członków wedle wymagań w stosunku do nich przez zrzeszonych w danej organizacji;

— działają i funkcjonują w sposób klarowny i transparentny pod względem kontaktów przykładowo administracyjnych ze stroną rządową lub samorządową (organami władzy publicznej);

— posiadają (w przypadku stałych grup interesu) program realizacji zamierzonych celów na dany rok;

— prowadzą monitoring całego procesu decyzyjnego i wdrażania projektów;

- udzielają informacji, dostarczają ekspertyzy i opnie pozwalające na forsowanie konkretnych decyzji;

- uparcie dążą do zamierzonych celów w granicach prawa, które pozwalają na osiagnnięcie takiego celu;

— funkcjonują w taki sposób, aby wypracowywać kompromis pomiędzy zainteresowanymi stronami.

\section{Głównym celem polskich grup interesów jest:}

— reprezentowanie różnych sektorów społeczno-gospodarczych (KIG, PKPP Lewiatan, ZBP, ZDS, RBF, PIPC);

- ochrona i reprezentowanie swoich członków w określonych sektorach;

— promowanie działan mających na celu eliminowanie zjawisk wpływających negatywnie na polską gospodarkę;

— podejmowanie inicjatyw sprzyjających polskim przedsiębiorcom, korporacjom i firmom;

— wydawanie opinii i ekspertyz;

— monitorowanie lobbowanych spraw;

— przyczynianie się do rozwoju gospodarczego kraju na poziomie regionalnym i lokalnym;

— członkostwo na poziomie ponadnarodowym - Unia Europejska.

Głównym celem oddziaływania polskich grup nacisku (,pressure groups”), jest implementacja i realizacja polityk wspólnotowych. Grupy nacisku nie ubiegają się o elektorat i nie próbują startować $\mathrm{w}$ wyborach $\mathrm{w}$ takim stopniu, w jakim czynią to ugrupowania polityczne. Starają się poprzez lobbing wywierać wpływ jako decydenci (z ang. decision-makers) w sposób 
bezpośredni lub pośredni na partykularne decyzje ${ }^{6}$. Generalnie grupy nacisku mają znacznie węższy obszar działania niż partie polityczne. Ugrupowania polityczne zajmują się w sposób gruntowny różnymi problemami na arenie politycznej, a grupy nacisku skupiają jedynie swoją uwagę na pewnych obszarach działania w ograniczonym rozmiarze.

Grupy interesu są organizacjami, które poprzez lobbing chcą wpływać na rządowe decyzje w sposób pośredni bez sprawowania urzędu.

Grupy biznesu zaczynają być postrzegane jako nierozłączne ogniwo polityczne, ekonomiczne, socjalne, prawne, które w kluczowych momentach decyduje o strategicznych decyzjach w UE, a jednocześnie zaczyna być dostrzegane jako piąta władza w procesie decyzyjnym Unii Europejskiej.

System instytucjonalny Unii Europejskiej jest otwarty dla grup interesu. W trakcie powstania Europejskiej Wspólnoty Węgla i Stali w 1951 roku była przewidywana jedynie ścisła współpraca z ,aktorami politycznymi” mająca na celu budowę jednoczącej się Europy. Art. 5 EWWiS brzmi następująco: Wspólnota wykonuje swoje zadania na warunkach przewidzianych $w$ niniejszym Traktacie, podejmujac działania o ściśle określonym zakresie: ułatwia działalność zainteresowanym, zbierajac informacje, organizując narady i określając główne cele; oddaje przedsiębiorcom do dyspozycji środki finansowe i bierze udziat w ponoszeniu kosztów ich adaptacji; [...]. Po wejściu w życie Traktatu rzymskiego (1957) ${ }^{7}$ w 1958 roku, Komisja Europejska wydała jedynie komunikat, który potwierdzał jedynie nawiązywanie współpracy i prowadzenie konsultacji z grupami interesu. Sam traktat ustanawiający Europejską Wspólnotę Gospodarczą nie zawiera żadnej regulacji prawnej dotyczącej grup interesu. Jedynie art. 118 mówi o ...ścisłej wspótpracy między Członkami Wspólnoty w dziedzinie zagadnień społecznych... Natomiast według art. 229 ust. 2 traktatu rzymskiego Komisja Europejska jest zobowiązana do utrzymywania kontaktów z organizacjami międzynarodowymi a w przypadku art. 245 ust. 2 traktatu o Unii Europejskiej Komisja jest uprawniona i zobowiązana do kontaktowania z rządami i grupami interesu. Jednolity Akt Europejski wypowiada się na temat współpracy w zakresie nauki i rozwoju technicznego krajów Wspólnoty Europejskiej z organizacjami międzynarodowymi i krajami trzecimi (grupy interesu są traktowane pośrednio przez Unię Europejską jako organizacje międzynarodowe) ${ }^{8}$. Traktat o Unii Europejskiej (Maastricht) ściślej uregulował problematykę grup interesu. Dotyczyła ona głównie spraw społecznych. Grupy interesu uzyskały inicjatywę prawną i przyjęły aktywną rolę w kreowaniu polityki społecznej w ramach Unii Europejskiej, a także umożliwił Komisji Europejskiej prowadzenie na większą skalę kontaktów z grupami interesu w zakresie tejże polityki. Traktat amsterdamski przyczynia się do umocnienia dialogu społecznego ${ }^{9}$. Przyjęte rozwiązania w Traktacie amsterdamskim dają możliwość prowadzenia ścisłej współpracy z państwami członkowskimi, prowadzenia badań, zaciagania opinii i konsultacji zarówno w zakresie polityki wewnętrznej i zewnętrznej w szczególności z organizacjami międzynarodowymi. Traktat nicejski pogłębia możliwość podejmowania współpracy grup interesu z Unią Europejską reprezentujących w szczególności interesy pracodawców i pracobiorców.

\footnotetext{
${ }^{6}$ Jednym z wyjątków jest w USA grupa nacisku Pro-Life Alliance, której jednym z głównych celów było uchylenie Aktu Aborcyjnego z 1967 roku (Abortion Act), a następnie grupa ta postanowiła wystawić 53 kandydatów do generalnych wyborów w 1997 roku, czy grupa „Referendum Party”, która także wystawiła dosyć znaczną liczbę kandydatów do wyborów (547 kandydatów).

${ }^{7}$ C. Michelle, European Union Politics, Oxford University Press Inc, New York 2005, s. 197-198.

${ }^{8}$ Ibidem.

${ }^{9} \mathrm{~W}$ szczególności jest o tym mowa w art. 136-148.
} 
Działalność polskich reprezentacji interesów regulują w systemie instytucjonalnym UE i polskim prawodawstwie następujące akty prawne:

- ustawa z dnia 23 maja 1991 roku o organizacjach pracodawców (Dz. U. Nr 55, poz. 235);

- ustawa z dnia 30 maja 1989 roku o izbach gospodarczych (Dz. U. Nr 35, poz. 195);

- ustawa z dnia 7 lipca 2005 roku o działalności lobbingowej w procesie stanowienia prawa (Dz. U. Nr 169, poz. 1414);

— Konstytucja Rzeczypospolitej Polskiej z dnia 2 kwietnia 1997 roku (w szczególności art. 57-59, 191);

- Traktat z Lizbony zmieniający Traktat o Unii Europejskiej i Traktat ustanawiający Wspólnotę Europejską z dnia 13 grudnia 2007 roku - wersja skonsolidowana (art. 11, 13);

- wersja skonsolidowana Traktatu o Funkcjonowaniu Unii Europejskiej (art. 154, 163, 207, 300).

Biorąc pod uwagę najważniejsze kryteria podziału (struktura organizacyjna i cel działalności polskich grup interesu) można wyróżnić następujące typy organizacji biznesowych ${ }^{10}$ :

- konfederacja (grupa utworzona przez organizacje dla osiagnięcia określonych celów, taka forma stowarzyszenia zakłada zachowanie pełnej równości - Polska Konfederacja Pracodawców Prywatnych Lewiatan - PKPP Lewiatan);

- federacja (składa się z mniejszych, obdarzonych autonomią organizacji związkowych, organizacji podległych, ale takich które posiadają wspólny zarząd, walne zgromadzenie - Federacja na rzecz Kobiet i Planowania Rodziny);

— związek (powiązanie większej liczby zrzeszonych organizacji reprezentowanych przez organ nadrzędny - Związek Banków Polskich - ZBP);

- stowarzyszenie (organizacja społeczna powołana przez jednostki mające wspólne cele lub zainteresowania - Stowarzyszenie Konsumentów Polskich - SKP);

— izba (organizacja, której celem jest obrona i promocja rozwoju określonego sektora gospodarczego-KIG);

— unia (dobrowolny związek dwóch lub więcej organizacji - UMP);

- rada (Polska Rada Biznesu - PRB).

Grupy interesu są postrzegane przez Unię Europejską jako pełnoprawni i niezbędni aktorzy w procesie podejmowania decyzji w UE. Różne wizje traktowania grup interesu ma Parlament Europejski i Komisja Europejska. W szczególności wielkim zwolennikiem grup interesu jest Komisja Europejska, która kładzie istotny nacisk na szeroko rozumianą komunikację. Jest zwolennikiem prowadzenia otwartego dialogu z grupami interesu („An Open and Structured Dialogue with Interest Groups" European Commission 1992b: 2) ${ }^{11}$. Podobną opinię (w formie dokumentu) wyraziła komisja w stosunku do relacji z pozarządowymi organizacjami w 2000 roku (NGOs - non-governmental organisations European Commision $2000 \mathrm{a})^{12}$ istnieje również wzmianka o dokumencie dotyczącym komunikacji z Instytucjami

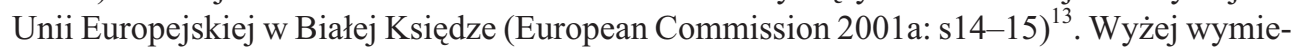
nione dokumenty stanowią jednak tylko bazę dla dialogu, jaki od tamtego momentu zaczął się rozwijać pomiędzy pracownikami Parlamentu Europejskiego, członkami i pracownikami Ko-

\footnotetext{
${ }^{10}$ www.kig.pl, www.pkpplewiatan.pl, www.federa.org.pl, www.zbp.pl, www.skp.pl, www.metropolie.pl, www.prb.pl.

11 www.europa.eu.int/comm/governance/index_en.htm.

12 Ibidem

13 Ibidem.
} 
misji oraz innymi organizacjami. Wcześniej zostały odnotowane tylko deklaracje współpracy grup interesu z instytucjami europejskimi. Wyżej wymienione dokumenty sprecyzowane przez Unię Europejską (wcześniej przez Wspólnotę) dają jedynie szerokie pole do prowadzenia konsultacji, rozmów i współpracy z wszystkimi aktorami mającymi wpływ na proces decyzyjny (pracownicy, parlamentarzyści, urzędnicy, komisarze...). Kontakty grup interesu do początku lat dziewięćdziesiątych były promowane jako spotkania nieformalne (spotkania ad-hoc). Wymienione akty przyczyniły się do przeformowania kontaktów nieformalnych w bardziej formalne (European Commission 2000a) ${ }^{14}$, co pozwoliło na zmianę i urozmaicenie spotkań roboczych przedstawicieli korporacji lobbingowych z Instytucjami Europejskimi. Pomimo wszelkich starań ze strony Unii Europejskiej dotyczących prób usankcjonowania działalności lobbingowych grup interesu nie zostały ustanowione żadne konkretne akty normatywne, jak ma to miejsce w Stanach Zjednoczonych, ale zostały wykrystalizowane pewne minimalne standardy współpracy z grupami interesu. Parlament Europejski wskazywał na brak dostatecznej przejrzystości w przepisach prawnych i w zachowaniu grup interesu (rodzaju lobbingu-wpływu). Po długich i burzliwych debatach na temat regulacji prawnych dotyczących lobbingu grup interesu w 1996 roku Parlament Europejski postanowił zaostrzyć nieco przepisy. Wprowadzono obowiazek rejestracji grup interesu (korporacje lobbingowe posiadają swoje tzw. kody dostępu - identyfikacja grupy interesu bądź organizacji pozarządowej lub innej). Grupy lobbingowe mogą otrzymać identyfikatory (z ang. badge) jedynie na jeden rok (później mogą być wznowione). W konsekwencji jest możliwa hierarchizacja odróżniająca interesantów od grup zainteresowanych lobbingiem w instytucjach Europejskich. Na początku identyfikator był identycznego koloru jak przepustki parlamentarzystów (zielony), a od października 2006 roku został wprowadzony kolor brązowy. Jest to czytelną formą ze względu na to, że można już taką osobę identyfikować z dalszej odległości. Każda rejestracja zawiera profil działalności firmy lobbingowej (korporacji czy organizacji) dane o pracownikach itd. Każda przepustka jest wydawana w formie imiennej, co w dużym stopniu ułatwia identyfikację interesanta. Kluczowym momentem we wprowadzaniu polityki transparencji lobbingu był rok 2008, kiedy to wówczas Komisja Europejska wprowadziła rejestr grup biznesowych i jednocześnie zaapelowała do grup interesu o opracowanie kodeksu postępowania reprezentantów grup biznesowych. Początkowo rejestr był wprowadzony próbnie na jeden rok, jednak jego sukces przejrzystości okazał się nadzwyczaj zaskakujący i postanowiono kontynuować ten rejestr. W przypadku polskich grup interesu rejestr obejmuje następujące organizacje $^{15}$ :

1) Specjalistyczne firmy doradcze lub kancelarie prawne zajmujące się lobbingiem przy instytucjach europejskich (2):

- kancelaria prawna;

- firma doradcza w dziedzinie spraw publicznych;

- niezależny konsultant $\mathrm{w}$ dziedzinie spraw publicznych (Kancelaria lobbingowa Carlo Paolicelli, Niezależny konsultant Piotr Wierzchowski);

- inna podobna organizacja;

2) „Wewnętrzne” grupy interesu oraz grupa prowadząca profesjonalną działalność lobbingową (8):

- przedsiębiorstwo;

\footnotetext{
${ }^{14}$ Ibidem.

${ }^{15}$ Stan na styczeń 2010 roku, https://webgate.ec.europa.eu/transparency/regrin/welcome.do?locale=pl.
} 
- organizacja zawodowa (Polski Związek Hodowców i Producentów Zwierząt Futerkowych, Północnoatlantycka Organizacja Producentów);

- związki zawodowe;

- inna podobna organizacja (KIG, PKPP Lewiatan, ZBP, ZDS, RBF);

3) Organizacje pozarządowe i zespoły ekspertów tzw. „Think-tanks” (12):

- organizacje pozarządowe i zrzeszenia organizacji pozarządowych (FNP, OPPRŚ, PIIP, PREPARE, SBF, SKP, SPRŁ, Itaniani in Polonia);

- zespoły ekspertów tzw. think-tanks (FR, demosEUROPA);

- inna podobna organizacja (Itaniani in Polonia);

4) Inne organizacje (5):

- instytucje akademickie (UL);

- organizacje religijne, kościoły i wspólnoty wiernych;

- stowarzyszenia władz publicznych (UMP, UBC);

- inna podobna organizacja (,Jeden Świat”, PSPR).

Transparencja grup biznesowych przyczyni się do postrzegania rzetelnego rzecznictwa grup interesu w granicach przestrzegania prawa. Według Komisji Europejskiej w ramach europejskiej inicjatywy na rzecz przejrzystości Komisja Europejska postanowiła utworzyć rejestr grup interesu i tym samym dać obywatelom możliwość dowiedzenia się, jakie interesy, ogólne lub specyficzne, maja wpływ na proces podejmowania decyzji przez instytucje europejskie oraz jakie środki przeznacza się na tego typu działalność. Rejestrując się dobrowolnie $w$ rejestrze, grupy interesu maja możliwość dowieść swojego zaangażowania na rzecz przejrzystości oraz legalności swego działania. Podczas procesu rejestracji zgłaszajacy zobowiazuja się do przestrzegania kodeksu postępowania lobbystów ${ }^{16}$.

Polskie grupy biznesowe określiły specyficzne zasady członkostwa, które należy spełnić, aby stać się pełnoprawnym członkiem. Poniżej przedstawiony jest ujednolicony schemat postępowania w przypadku przyjmowania w poczet członków, który obejmuje następującą procedurę:

1) złożenie pisemnego wniosku;

2) spełnienie kryteriów członkowskich;

3) zapoznanie się ze statutem i wysokością składek członkowskich;

4) wypełnienie dodatkowej deklaracji (np. Związek Dealerów Samochodów - ZDS);

5) zarząd organizacji lub organ właściwy do podejmowania decyzji rozstrzyga wniosek;

6) w razie odmowy - przysługuje rozpatrzenie odwołania - właściwy organ decyzyjny;

7) przyjęcie w poczet członków lub odmowa.

Ważną kwestią na jaką należy zwrócić również uwagę jest budowa struktur organizacyjnych polskich organizacji biznesowych. Struktura poszczególnych grup społeczno-ekonomicznych i branżowych funkcjonuje w sposób sformalizowany i zbliżony jak w przypadku organizacji, które lobbują na poziomie Unii Europejskiej. Systematyzując można przedstawić budowę organizacji w następujący sposób ${ }^{17}$ :

Polskie grupy interesu są powoływane głównie w określonym celu, aby realizować zamierzone postulaty programowe. Analizując poszczególne polskie grupy biznesowe można zauważyć, że ich ramy programowe i cele realizowane są poprzez:

\footnotetext{
${ }^{16} \mathrm{https}: / /$ webgate.ec.europa.eu/transparency/regrin/welcome.do?locale=pl.

${ }^{17}$ Struktura organizacyjna opracowana na podstawie statutów następujących organizacji: KIG, PIPC, PKPP Lewiatan, PZHiPZF, RBF, ZDS, ZBP, SBF, SKP, SPRŁ, SRRR, UL, UMP, UBC, PSPR, demosEuropa.
} 
Struktura organizacyjna

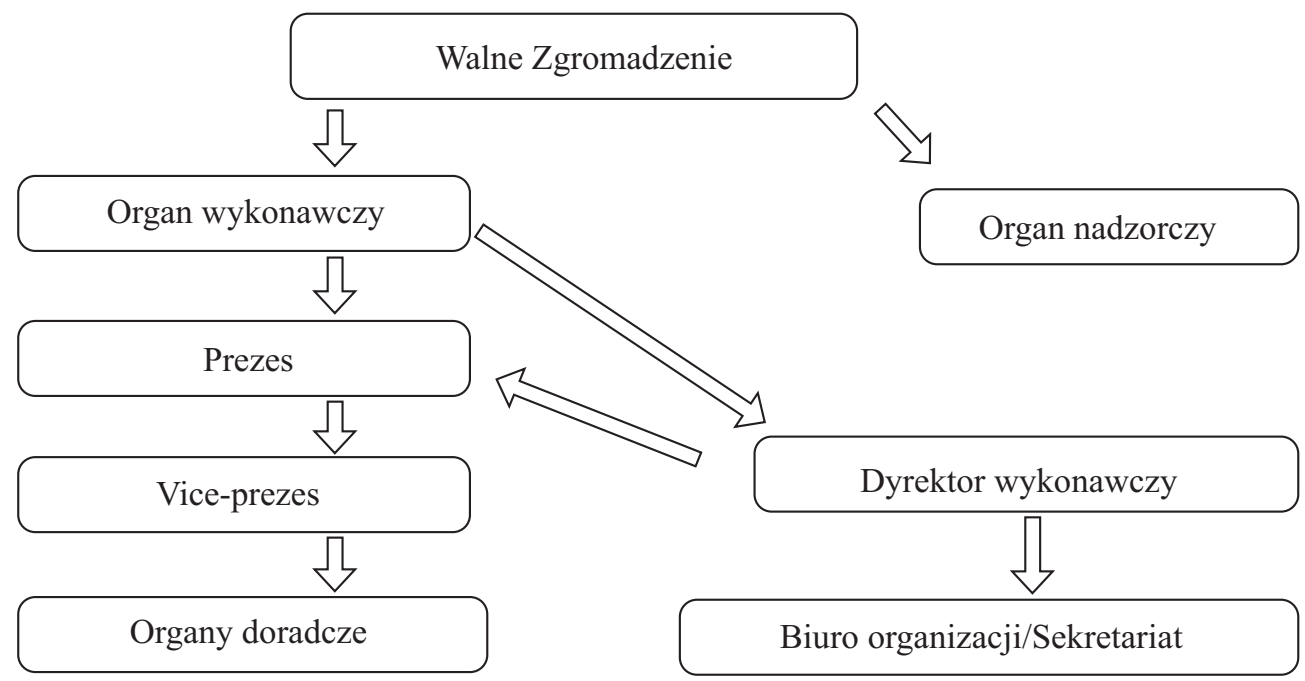

— skuteczne reprezentowanie swoich członków i podmiotów gospodarczych na poziomie narodowym i ponadnarodowym;

- tworzenie przyjaznego prawa dla przedsiębiorców;

- prowadzenie działalności edukacyjnej;

— wydawanie opinii i ekspertyz;

— działanie na rzecz rozwoju przedsiębiorczości w nowoczesnych formach technologiczno-organizacyjnych;

— inspirowanie i prowadzenie nowelizacji prawa gospodarczego i przepisów związanych z działalnością zawodową członków poszczególnych organizacji;

— kształtowanie zasad etyki i podnoszenie norm w relacjach gospodarczych;

— prowadzenie pośredniej działalności będącej efektem rzetelnego rzecznictwa interesów;

— wykonywanie zadań zapisanych w statutach organizacji biznesowych.

Grupy interesu w procesie decyzyjnym odgrywają znaczące role w kwestii stanowienia prawa polskiego i europejskiego. Wypełniają w nim funkcje: negocjacyjno-pośrednicząca, innowacyjną, regulacyjno-prawną, informacyjno-pośrednicząca, konsultacyjną, nadzorującą i edukacyjną.

- funkcja negocjacyjno-pośrednicząca przyczynia się do wypracowania legitymizacyjnych standardów. Dzięki tej funkcji minimalizuje się wiele rozbieżności, co pozwala na znalezienie odpowiedniego konsensu dla wszystkich stron (pracodawca - konsument - instytucje europejskie - grupy interesu). Funkcja ta jest formą wypracowywania określonego kompromisu, takiego, który daje szeroko rozumianą satysfakcję dla wszystkich zainteresowanych aktorów zajmujących się politycznym wymiarem funkcjonowania Unii Europejskiej;

- funkcja innowacyjna, jest pewną formą wdrażania rozwiązań mających na celu dobro konsumentów-pracodawców. Pozwala na efektywną współpracę z instytucjami europejskimi poprzez wdrażanie ciekawych innowacji i nowoczesnych rozwiązań będących kluczem do budowy silnej Unii Europejskiej w różnych branżach i na wielu 
płaszczyznach. Pozwala na znalezienie najbardziej celowych i kompromisowych rozwiązań;

- funkcja regulacyjno-prawna daje szerokie możliwości aktywnego uczestnictwa w procesie tworzenia normatywnych aktów prawnych, a także wdrażania nowatorskich rozwiązań, które poprawią dotychczasowe regulacje prawne. W tym przypadku korporacje lobbingowe biorą czynny udział w legitymizacji prawa w procesie decyzyjnym. Ich działania dotyczą wszystkich faz procesu tworzenia prawa;

- funkcja informacyjno-pośrednicząca sprowadza się do wymiany informacji. Dzięki współpracy z instytucjami europejskimi i zainteresowanymi, grupy interesu stają się swego rodzaju ogniwem pośredniczącym w wymianach informacji. Jest to przydatne w trakcie szukania odpowiedniego rozwiązania, które będzie kluczem do stworzenia odpowiednich aktów prawnych;

- funkcja konsultacyjna, polega na udzielaniu rzeczowych konsultacji i opinii w celu udoskonalenia w różnych branżach polityki UE oraz poszczególnych krajach członkowskich. Jej celem jest udoskonalanie i poprawianie wizerunku jakościowego polityki UE. Taki proces konsultowania może wpływać na poprawę postrzegania polityki Unii Europejskiej $^{18}$;

- funkcja nadzorująca, która sprowadza się do monitorowania i kontrolowania wprowadzanych decyzji i rozwiązań;

- funkcja edukacyjna, która polega na prowadzeniu szkoleń, kursów, promowaniu działań mających na celu podnoszenie poziomu wiedzy na dany temat.

Grupy interesu wypełniając wyżej wymienione funkcje stosują różne taktyki i techniki. Każda sprawa jest z reguły indywidualnym rozwiązaniem i nie należy obierać jednakowej zasady działania. Stąd zostały wypracowane poszczególne techniki lobbingu, które zawierają identyfikację celu, selekcję określonych pytań mających znaczenie dla projektu, znalezienie kluczowych możliwości, podjęcie decyzji o zastosowaniu taktyki i mechanizmów kontroli.

Rzetelne rzecznictwo interesów polskich grup biznesowych jest formą polegającą na prowadzeniu dialogu pomiędzy instytucjami biorącymi udział w procesie decyzyjnym kraju, jak i na poziomie UE. Metody, jakimi posługują się organizacje biznesu w celu wywierania nacisku na urzędnikach szczebla decyzyjnego przyjmują różną formę. Główną przyczyną jest istota prowadzenia lobbingu na różnych poziomach decyzyjnych w odmiennym lub tym samym czasie. Taka klasyfikacja wymuszana jest przez proces podejmowania decyzji w UE i na polskim poziomie. Jednocześnie taki proces podejmowania decyzji wymusza na grupach biznesowych stosowanie następujących form wpływu w systemie instytucjonalnym UE:

- formalny i nieformalny (wpływ formalny polega na wypracowaniu kompromisu przez oficjalne reprezentowane stanowiska przez grupę biznesową - np. oficjalne spotkania, natomiast nieformalny wpływ lub czasem półformalny polega na wypracowaniu stanowiska poprzez kanały nieoficjalne np. prywatne spotkania);

— bezpośredni i pośredni (bezpośrednia forma wpływu - np. spotkania twarzą w twarz, zaś pośrednia metoda wpływu - dostarczenie ekspert naukowych przez niezależną stronę trzecią);

— wymiana informacji (dostarczanie i żądanie otrzymywania informacji od organów decyzyjnych na poziomie narodowym lub UE);

\footnotetext{
${ }^{18}$ L. Graniszewski, C. Piątkowski, Grupy interesu w Unii Europejskiej, Warszawa 2004, s. 88.
} 
- wpływ ofensywny i defensywny (forma ofensywna polega na wyprzedzeniu faktu podjęcia decyzji przez organ decyzyjny, jest to tak zwana forma ataku, natomiast wpływ defensywny jest procesem mającym na celu obronę zachowania dotychczasowej decyzji, tak zwane zachowanie statusu quo);

— odgórny i oddolny (oddolny wpływ, który polega na prowadzeniu lobbingu na poziomie najniższego szczebla - tak zwany „grassroots lobbying”, a także odgórna forma - czyli wywieranie presji lobby na najwyższych urzędnikach organów decyzyjnych -np. Komisarzy UE lub szczeblu ministerialnym na polskim poziomie);

— inne formy wpływu:

- Internet;

- budowanie wizerunku (budowanie wizerunku organizacji lobbingowej);

- zawiązywanie koalicji (prowadzenie kampanii razem z innymi organizacjami biznesowymi);

- medialny (poprzez media);

- adaptacyjny (dostosowanie lobbingu do danej sytuacji i nieprzewidywalnych zmian);

- „Mickey Mouse” (słynna kafeteria w Parlamencie Europejskim, gdzie zapadają między sesjami plenarnymi kluczowe decyzje, głosowanie jest często jedynie formalnością);

- procesowe instrumenty wpływu (komunikacja telefoniczna, e-mail, spotkania robocze, listy itd.).

Działalność grup interesu w głównej mierze polega na aktywnym udziale w procesie decyzyjnym UE i na szeroko rozumianej współpracy z instytucjami wspólnotowymi lub organami władzy państwowej na polskim poziomie. Wśród licznych aktorów biorących udział w procesie decyzyjnym UE i będących w obszarze zainteresowań lobbystów na poziomie europejskim jest: Komisja Europejska, Parlament Europejski, Rada Unii Europejskiej, Europejski Trybunał Sprawiedliwości, Komitet Regionów, Komitet Ekonomiczno-Społeczny, a na poziomie polskim są np. posłowie RP, urzędnicy administracji państwowej czy poszczególni ministrowie określonych resortów - np. minister gospodarki, skarbu itd.

Poszczególne grupy biznesowe mają znaczący wpływ na rozwój gospodarczy Polski czy integrację gospodarczą UE. Jedną z najbardziej aktywnych organizacji na polskim gruncie jest Polska Konfederacja Pracodawców Prywatnych Lewiatan - PKPP Lewiatan. Konfederacja przyczyniła się między innymi do wprowadzenia zmian i wypracowania kompromisów w następujących obszarach gospodarczych w Polsce ${ }^{19}$ :

— ustawa o swobodzie działalności gospodarczej;

— 19\% CIT i PIT od działalności gospodarczej;

- nowelizacja Kodeksu spółek handlowych (własny projekt);

- w ustawie o tzw. radach pracowników - przyjęcie progu zatrudnienia, od którego istnieje obowiązek powoływania rad na poziomie 50 zatrudnionych (strona związkowa postulowała 5 , a strona rządowa 20 );

- zmiany w prawie branżowym:

- nowelizacja prawa własności przemysłowej,

- okresy przejściowe dla producentów leków generycznych i producentów tytoniu,

- niższy VAT na budownictwo mieszkaniowe po wejściu do UE;

— zmiany w Kodeksie Pracy:

- wydłużenie okresów rozliczeniowych czasu pracy (4, 6, 12 miesięcy),

\footnotetext{
${ }^{19} \mathrm{http} / / /$ www.pkpplewiatan.pl/?ID=66524.
} 
- wprowadzenie nowego rodzaju umowy o zastępstwo,

- zniesienie obowiązku wydawania regulaminów pracy i wynagrodzeń dla firm zatrudniających do 20 pracowników,

- wyłączenie małych firm - zatrudniających do 20 pracowników - ze stosowania ustawy o zwolnieniach grupowych;

— kampania Inicjatywy Obywatelskiej „Tak w referendum” na rzecz akcesji Polski do Unii Europejskiej.

W kuluarach instytucji europejskich grupy interesu (korporacje lobbingowe, grupy nacisku) są coraz częściej nazywane jako piąta władza z mocą prawną w Unii Europejskiej. W konsekwencji należy stwierdzić, że grupy interesu stają się w coraz to większym stopniu aktorami europejskimi, którzy w szerokim kontekście mają wpływ na proces decyzyjny Unii Europejskiej i tym samym odgrywają kluczową rolę w budowie jednoczącej się gospodarczo i politycznie Europy.

\section{Konkludując polskie grupy biznesowe:}

- pełnią rolę pośredniczącą;

- mają duży wpływ na rozwój gospodarczy każdego kraju członkowskiego w UE;

- są nieodłącznym ogniwem systemu demokratycznego;

— stymulują rozwój gospodarczy;

— wpływają na legislację i proces decyzyjny;

— zmieniają, inicjują i modyfikują decyzje polityczne;

- reprezentują określone grupy społeczno-gospodarcze;

- wpływają na rozwój integrującej się Europy i umacniają tym samym pozycję UE na poziomie międzynarodowym.

\section{Bibliografia}

\section{Monografie:}

A. F. Butt, Pressure Groups in the European Community, London 1985.

B. Coxall, Pressure Groups in the British Politics, London 2001.

B. Woszczyk, Lobbing w Unii Europejskiej, Toruń 2004.

D. Prag, Lobbying the European Community, London 1983.

E. Kirchner, K. Schwaiger, The Role of the Interest Group in the European Community, Hampshire 1981.

E. Bomberg, A. Stubb, The European Union: How Does It Work?, Oxford 2006.

G. Pascal, Lobbying In Brussels, Brussels 2006.

J. Greenwood, Inside the EU Business Associations, New York 2002.

J. Greenwood, Representing Interest in the European Union, London 1997.

J. Greenwood, Reprezentacja Interesów w Unii Europejskiej, Londyn 2003.

J. Hayward, A. Menon, Governing Europe, Oxford, New York 2003.

J. L. Zorack, The Lobbying Handbook, Washington 1990.

J. Richardson, European Union, Power and policy-making, London 2004.

J. Richardson, European Union, Power and policy-making, London 2006.

J. Richardson, Pressure Groups, Oxford 1993.

K. Joos, F. Waldenberger, Successful Lobbying in the New Europe, Berlin 2004.

L. Graniszewski, C. Piątkowski, Grupy Interesu w Unii Europejskiej, Warszawa 2004. 
M. Borucki, Stownik o Unii Europejskiej, 2004.

M. Cini, European Union Politics, Oxford University Press Inc, New York 2005.

M. P. Heywood, Developments in the European Politics, New York 2006.

P. Bouwen, Corporate Lobbying in the European Union: Towards a Theory of Access, San Domenico 2001.

R. Van Schendelen, Machiavelli in Brussels, The Art of Lobbying the EU, Amsterdam 2005.

S. H. Ainsworth, Analyzing Interest Group, Group Influence on People and Policies, New York 2002.

S. Hix, The political System of the European Union, London 2005.

S. Mazey, J. Richardson, Lobbying in the European Community, Oxford 1993.

U. Kurczewska, M. Molenda-Zdziech, Lobbing w Unii Europejskiej, Warszawa 2002.

\section{Prace zbiorowe:}

K. A. Wojtaszczyk, Encyklopedia Unii Europejskiej, Warszawa 2004.

K. A. Wojtaszczyk, System instytucjonalny Unii Europejskiej, Warszawa 2005.

\section{Internet:}

https://webgate.ec.europa.eu/transparency/regrin/welcome.do?locale=pl.

www.europa.eu.int/comm/governance/index_en.htm.

www.federa.org.pl.

www.kig.pl.

www.metropolie.pl.

www.pkpplewiatan.pl.

www.prb.pl.

www.skp.pl.

www.zbp.pl.

\section{Summary}

The main aim of this paper is to demonstrate what role Polish business groups play at a supranational level. In Poland reliable advocacy of individual interests by Polish business groups brings negative associations, and the lobbying Polish business groups apply is perceived as an unfair way of exerting pressure on the authorities. Therefore, this paper outlines the conceptualization of the network of notions pertaining to Polish business groups. Lobbying is presented as an instrument applied by professional teams of lobbyists in lobbying campaigns aimed at exerting influence in a transparent, substantive and fair manner. The specificity of interest groups and the stages that affect the emergence of individual Polish business groups are also analyzed. The aspect of legal regulations concerning lobbying activity conducted at a national and supranational level is presented. The picture of the organizational structure, the functions business groups have in the Polish and EU law-making process are discussed as well. The paper also shows the forms of influence used by Polish business groups and exemplifies advantageous activities that contribute to the economic development of Poland. 
